\title{
Bacteriological status of ashtoum El-Gamil protected area
}

\author{
Abdelhamid M. Abdelhamid ${ }^{1}$ Manal I. El-Barbary ${ }^{2}$ and \\ El-Deweny M. E. Mabrouk ${ }^{1}$
}

1- Dept. of Animal Production, Fac. of Agriculture, Mansoura Univ., Mansoura, Egypt

2-Fish Pathology Lab., National Institute for Oceanography and Fisheries, Cairo, Egypt.

\section{ABSTRACT}

Survey study was carried out throughout four seasons from four locations representing the whole protected area "Ashtoum El-Gamil", Port Said governorate, Manzala Lake concerning the bacterial load in water and fish of this park. The bacterial load in water samples increased by increasing water temperature, the range of total count of bacteria was $0.6 \times 10^{6}$ to $0.2 \times 10^{8} / 100 \mathrm{ml}$ of water sample in winter and summer respectively. The following bacterial genera were isolated from water samples: Aeromonas, Bacillus, Proteus, Pseudomonas, Streptococcus, S. epidermidis, S. aureus, Micrococcus, Vibrio and E. coli. The predominant microorganisms isolated from water were E. coli, Bacillus spp., Vibrio spp. and Pseudomonas spp. While the total bacterial counts (TBCs) from fish samples obtained on NA media were higher in summer season in all tested organs than other seasons (spring, winter and autumn); also, the high bacterial load was observed in both of gills and intestine comparing with the liver. TBCs were $0.8 \times 10^{7}, 0.52 \times 10^{7}$ and $0.13 \times 10^{7} \mathrm{cfu} / \mathrm{g}$ in gills, intestine and liver, respectively in location No. 3 (bahr kassab) during the summer. The highest TBCs obtained on McCA, MSA, and BHA media were $0.16 \times 10^{7}, 0.25 \times 10^{7}$, and $0.3 \times 10^{7} \mathrm{cfu} / \mathrm{g}$ of gills in locations No. 1, 1 and 3 during summer, autumn and summer, respectively. The bacterial species isolated also from fish were namely $V$. cholerae, V. parahaemolyticus, Aeromonas spp., E. coli, Yersinia spp., Proteus, Pseudomonas spp., Micrococcus spp., S. epidermidis, S. aureus and Streptococcus spp. In the pathogenicity test, the most pathogenic bacteria for tilapia fish were Pseudomonas spp., V. cholerae and Aeromonas spp which causing greater than 70 , $60 \%$ and $60 \%$ mortality within $96 \mathrm{hr}$ respectively.

Keywords: Ashtoum El-Gamil - water - fish - bacteria.

\section{INTRODUCTION}

Ashtoum El-Gamil protected area was found according to the Prime ministerial decree No. 459 for 1988 . Its location: $31^{\circ} 15^{\prime} \mathrm{N} 32^{\circ} 10^{\prime} \mathrm{E}$. Ashtoum El-Gamil is located in the western north corner of Lake Manzala, Egypt including new and old El-Gamil inlets, Lake Manzala the largest and most productive of the Nile Delta wetlands and situated at the North Eastern part of the Nile Delta between the Suez Canal and Damietta Nile branch, the area is approximately $175 \mathrm{~km}^{2}$ and is completely located inside the lagoon. The main purpose for creating this protected area was the protection of many resident and migratory species of birds, saline and fresh water fish, natural plants and historical sites scattered throughout the lagoon. Ashtoum El-Gamil represents a modest example of a highly threatened and rapidly disappearing habitat in Egypt and the Mediterranean basin (Ibrahim, 1993 and Meininger and Atta, 1994). However, there is a proposal to increase the size of this protected area to encompass larger, more important parts of Manzala lagoon. The aquatic ecosystem consists of several components which are directly or indirectly affected by pollution (Kosygin et 
al., 2007). The pollution of a particular water body can always be linked to an industry, sewage or agricultural drainage (Subramanyam and Sambamurty, 2006 and Sathware et al., 2007). Special attention has been paid to the effect of environmental pollution from microbiological and toxicological points of view (Zaki, 1995). Microbiological quality is assessed by monitoring the abundance of indicator bacteria that are associated with recent faecal contamination. Clark and Pagel (1977) considered bacteria as a reliable indicator of contamination. Bacteria play an important role in global ecosystems which are major factors in controlling the quality of water and are fate determinators of pollution released to environment (Atlas and Bartha 1993). Several investigators selected coliform bacteria and faecal streptococci to assess the pollution in marine environment (Mancini, 1978; Lara et al., 1991; ElNaggar et al., 2003 and El-Shenawy and Farag, 2005). High levels of faecal indicator bacteria in aquatic environment might indicate the presence of pathogenic microorganisms. Cholera, typhoid fever, bacterial dysentery and other infectious diseases are spread through contaminated water with faecal matter (Rose et al., 1996). The aim of the present study was to investigate the present bacteriological status of this park.

\section{MATERIALS AND METHODS}

\section{Sampling locations:}

Lake Manzala is the largest of the Nile Delta lakes. It is located in the northeastern part of Egypt. It is bounded on the east by the Suez Canal and on the west by Damietta branch of the Nile and is separated from the Mediterranean Sea by a narrow sandy fringe at the north. The lake is connected to the Mediterranean Sea through a narrow channel (Boughaz El-Gamil). The islands and reed beds divide the lake into well defined basins each is known as Bahr having more or less distinctive ecological conditions (Abdel-Baky et al., 1991). Samples were collected from Ashtoum El-Gamil Protected Area which is located in the western north corner of Lake Manzala including new and old El-Gamil inlets. Samples were collected from four stations, being: station No. 1: inlet of El-Gamil old in the north-east, station No. 2: inlet of El-Gamil new in the north-west, station No. 3: bahr Kassab near to the middle, station No. 4 and bahr Bashtier in the south-west station.

\section{Water samples:}

Water samples were collected seasonally in clean 1 liter polyethylene bottles from a depth of $50 \mathrm{~cm}$ of the sampling locations.

\section{Fish samples:}

Tilapia and mullet fish were selected for the present study and collected from four sites in Ashtoum El-Gamil protectorate during the four seasons from May 2010 to January 2011, where these species have a wide range of distribution in the aquatic habitat in Egypt. Fish samples were transported immediately to the laboratory in an ice-box for the bacteriological examination.

\section{Bacteriological examination: \\ Cultivation media:}

The general and specific cultivation media used in this investigation for different purposes were nutrient agar (NA) for counting the total bacteria, MacConky agar (MacCA) for detecting coliform bacteria, Rimler-Shotts (RS) Medium Base was used for selective isolation, cultivation and presumptive identification of Aeromonas hydrophila. Thiosulfate Citrate Bile Sucrose Agar (TCBS) medium was used for the isolation and selective cultivation of Vibrio cholerae and other enteropahtogenic vibrios (V. parahaemolyticus). Mannitol salt agar (MSA) medium was specifically 
used for isolation of Staphylococcus spp. Brain heart agar (BHA) a solid medium which contains the highly nutritious infusions recommended for the cultivation of fastidious organisms (Streptococcus and Neisseria).

Preparing samples for bacteriological examination:

From every sampling location (No. 1 and No. 2 mullet while No. 3 and No. 4 Nile tilapia), 3 fish / season were used for bacterial counts in fish organs (gills, liver and intestine). The fish samples were placed in sterile plastic bags and transferred to laboratory, in ice box. The number of incidental organisms was reduced by washing the fish skin with $70 \%$ ethanol before taking the gills and opening the ventral surface with sterile scissors to expose the body cavity. From each fish, $1 \mathrm{~g}$ of each tested organ was removed and suspended in $10 \mathrm{ml}$ of sterile saline $(0.85 \%(\mathrm{w} / \mathrm{v}) \mathrm{NaCl})$

under complete aseptic conditions. The suspension was serially diluted to $10^{3}$, and 1 $\mathrm{ml}$ of the solution was spread in each medium plate. The inoculated plates were cultured as described above and the number of colonies was counted. Water samples were collected in sterile glass bottles. Appropriate serial dilutions of fish and water samples were then plated onto plate count agar.

Aerobic plate count (APC):

For total heterotrophic aerobic bacterial counts of water, gills, liver and intestine of fish samples from different locations and seasons, all the inoculated plates were incubated at $37^{\circ} \mathrm{C}$ for $48 \mathrm{~h}$ and colony forming units (cfu) were counted. The temperature and incubation time used were found to be suitable for the growth of the investigated bacteria. Readings obtained with 30 to 300 colonies on a plate were used to calculate bacterial population numbers, recorded as cfu per volume/weight unit of sample. The bacterial colonies were divided into different types according to the colony characteristics of shape, size, color and opacity, and the number of colonies of each recognizable type was counted. Three to five representatives of each colony type were then streaked on additional plates repeatedly until pure cultures were obtained.

\section{Identification of bacteria isolates:}

Identification of isolated bacteria were carried out by studying the growth characters of colonies as well as smears were prepared from the colonies and stained with Gram's stain and examined microscopically for demonstrating the morphology, arrangement and staining reaction of microorganism. The bacteria isolates were finally identified according to schemes of biochemical reactions provided in Bergey's Manual of Systematic Bacteriology (Holt et al., 1994)

\section{Pathogenicity of some isolated bacteria:}

A total number of 80 apparently healthy Oreochromis niloticus with a mean body weight $40 \mathrm{~g}$ were obtained from El-Serw fish farm. The fish were divided into 8 groups each group contained 10 fish. The fish were maintained in $50 \mathrm{~L}(70 \times 40 \times 30$ $\mathrm{cm})$ aquaria with aerated fresh water for 2 weeks and fed commercial pellets in order to adapt to laboratory conditions prior to experimental infection with the seven bacteria isolates. Ten fish in each group were injected intramuscularly (i.m.) below the dorsal fin using 21-gauge sterile needle with $0.1 \mathrm{ml}$ of a suspension containing $10^{5}$ $\mathrm{cfu} / \mathrm{ml}$ in phosphate buffered saline (PBS). The 10 control fish were injected with PBS alone. The observation time was 7 days. The pathogenicity test was considered positive when more than $50 \%$ of the injected fish showed clinical signs and died within $96 \mathrm{hr}$. 


\section{RESULTS AND DISCUSSION}

\section{Microbiological examination of water:}

In order to detect the pathogenic bacteria, the water samples were conducted using a cultivation medium (NA). Data in Table 1 exhibited low bacterial loads of all winter samples but high level in summer, spring and autumn, respectively. The bacterial load in water samples increased by increasing temperature. The range of total count of bacteria was $0.6 \times 10^{6}$ to $0.2 \times 10^{8} \mathrm{cfu} / 100 \mathrm{ml}$ of water sample in winter and summer, respectively.

Table 1: Total counts $(\mathrm{cfu} / 100 \mathrm{ml})$ of bacteria obtained on nutrient agar (NA) medium from water samples collected from different locations and seasons.

\begin{tabular}{|c|c|c|c|c|}
\hline Location & \multicolumn{4}{|c|}{ Season } \\
\hline & Spring & Summer & Autumn & Winter \\
\hline $\mathbf{1}$ & $0.20 \times 10^{8}$ & $0.20 \times 10^{8}$ & $0.20 \times 10^{7}$ & $0.60 \times 10^{6}$ \\
\hline $\mathbf{2}$ & $0.15 \times 10^{8}$ & $0.20 \times 10^{8}$ & $0.19 \times 10^{7}$ & $0.70 \times 10^{6}$ \\
\hline $\mathbf{3}$ & $0.16 \times 10^{8}$ & $0.20 \times 10^{8}$ & $0.30 \times 10^{7}$ & $0.70 \times 10^{6}$ \\
\hline $\mathbf{4}$ & $0.20 \times 10^{8}$ & $0.10 \times 10^{8}$ & $0.30 \times 10^{7}$ & $0.70 \times 10^{6}$ \\
\hline
\end{tabular}

The genera of bacteria isolated from water samples varied according to the water salinity. The range of bacterial isolates obtained from water samples is shown in Table 2. Species of bacteria isolated are belonging to the genera Aeromonas, Bacillus, Proteus, Pseudomonas, Streptococcus, Staphylococcus, Micrococcus, Vibrio and Escherichia coli. The predominant microorganisms isolated from water were Bacillus spp., Pseudomonas spp., Vibrio spp. and E. coli. While the maximum calculated values of total count of faecal coliform bacteria (as E. coli) in water samples were recorded clearly in sites number 3 and 4 (bahr Kassab and bahr Bashtier) which are considered fresh water. It is probably due to the effect of untreated waste water at the area.

Table 2: Some identified bacteria isolated from water.

\begin{tabular}{|c|c|c|c|c|c|c|c|c|c|c|c|c|c|c|c|c|}
\hline \multirow[t]{3}{*}{ Bacteria isolate } & \multicolumn{16}{|c|}{ Seasons / Locations } \\
\hline & \multicolumn{4}{|c|}{ Spring } & \multicolumn{4}{|c|}{ Summer } & \multicolumn{4}{|c|}{ Autumn } & \multicolumn{4}{|c|}{ Winter } \\
\hline & 1 & 2 & 3 & 4 & 1 & 2 & 3 & 4 & 1 & 2 & 3 & 4 & 1 & 2 & 3 & 4 \\
\hline Vibrio spp. & + & + & + & + & + & + & + & + & + & + & + & + & - & + & - & - \\
\hline Aeromonas spp. & + & + & - & + & + & + & + & + & + & - & + & - & - & + & - & + \\
\hline Pseudomonas spp. & + & + & + & + & + & + & + & + & + & + & - & + & + & + & + & + \\
\hline E. coli & - & - & + & + & - & + & + & + & + & + & + & + & + & - & + & - \\
\hline Bacillus spp. & + & + & + & + & + & + & + & + & + & + & + & + & + & + & + & + \\
\hline Proteus & + & - & - & + & - & - & + & + & - & - & + & + & - & - & + & + \\
\hline Micrococcus spp. & + & + & + & + & - & - & + & - & + & + & + & + & + & - & + & + \\
\hline S. epidermidis & + & - & + & - & - & + & - & - & + & + & + & + & - & - & + & - \\
\hline S. aureus & + & - & - & - & + & + & - & + & + & + & + & + & - & - & + & + \\
\hline Streptococcus spp. & + & + & + & + & + & - & + & - & + & + & + & + & - & - & + & + \\
\hline 1: inlet of El-Gamil old & & & & & & & & & & & & & & & & \\
\hline
\end{tabular}

The occurrence of pollution indicator bacteria is used as sanitary parameters for evaluation of water quality. Shaltout et al. (2009) counted the total microbial count including fungi, yeasts and highest total bacterial counts (TBCs) as indicators for faecal pollution in Kafr El-Zayat industrial area. According to Egyptian Guidelines, which accept the guide values of investigated bacteria by 500 bacterial counts $/ 100 \mathrm{ml}$ 
sea water for coliform bacteria and 100 bacterial counts $/ 100 \mathrm{ml}$ sea water for E. coli and faecal streptococci (EEAA, 1999).

The present results are in agreement with Uddin et al. (1990), Fernandes et al. (1997) and Al-Harbi (2003). They found the bacterial load in water samples increased by increasing water temperature and organic matter. Also, these results support those of Hamed et al. (2013), the maximum calculated values of total count viable bacteria (TVB) in water samples were found in El-Bashtier (fresh water), when mean $\mathrm{pH}$ was 7.8 and mean water temperature $22.3^{\circ} \mathrm{C}$ in the presence of water current of $0.016 \mathrm{~m} / \mathrm{sec}$. It is probably due to the effect of untreated waste water at the drain which its spill near was investigated. Zaky et al. (2011) came to the same conclusion, where their results showed that there were a massive pollution in the lake with a high load of suspended solids and other pollutants. This exceeds the national standards of the Egyptian law No. 9 for year 2009. Counts of total viable bacteria in water were mostly higher in summer months, particularly in water samples in most sites with mean value $0.16 \times 10^{7} / 100 \mathrm{ml}$ in El-Bashtier and $0.91 \times 10^{7} / 100 \mathrm{ml}$ in El-Gamil areas. In general, most of the investigated areas have relative low levels of bacteria. However 19 stations showed high counts of one or more indicating bacteria exceeding the acceptable levels during at least one or more of the sampling campaigns. These stations are: El-Gamileast and also in El-Gamil-West.

Zaky (1995) mentioned that pollution of Lake Manzala is one of the most important national problems in Egypt, where bad environmental situation of the lake is reflected on the public health of people as an element of the ecosystem. Also, increase of Aeromonas sp. in Lake Manzala could be due to some environmental factors, such as ammonia and nitrate (Zaky, 2004). Moreover, Aeromonas spp. was always found in the faecal polluted water, such as waste water ponds, fresh and brackish eutrophic estuaries and lagoons (Sciavano et al., 1998; Marcel et al., 2002 and Platt et al., 2006).

\section{Bacteriological examination of fish organs:}

The results of the total count of bacteria isolated on different media and from different organs of tilapia and mullet organs from different locations and seasons are shown in (Table 3). In the present study, the high bacterial load was observed more dominant, generally, in gills and intestine, respectively. A total of 10 bacterial species were isolated and identified, with most of the isolates from gills, intestine and liver, respectively (Table 4).

Table 3: Counts of bacteria obtained on nutrient agar (NA) medium from different organs of fish samples collected from different locations and seasons.

\begin{tabular}{|c|c|c|c|c|}
\hline \multirow[b]{2}{*}{ Season } & \multirow[b]{2}{*}{ Location } & \multicolumn{3}{|c|}{ Bacterial count (cfu/g) } \\
\hline & & Liver & Gills & Intestine \\
\hline \multirow{4}{*}{ Spring } & 1 & $0.50 \times 10^{5}$ & $0.15 \times 10^{6}$ & $0.80 \times 10^{5}$ \\
\hline & 2 & $0.15 \times 10^{6}$ & $0.30 \times 10^{6}$ & $0.20 \times 10^{6}$ \\
\hline & $\frac{2}{3}$ & $0.50 \times 10^{6}$ & $0.10 \times 10^{6}$ & $0.80 \times 10^{5}$ \\
\hline & 4 & $0.50 \times 10^{5}$ & $0.10 \times 10^{6}$ & $0.80 \times 10^{5}$ \\
\hline \multirow{4}{*}{ Summer } & 1 & $0.20 \times 10^{5}$ & $0.10 \times 10^{7}$ & $0.80 \times 10^{6}$ \\
\hline & 2 & $0.20 \times 10^{5}$ & $0.10 \times 10^{7}$ & $0.10 \times 10^{6}$ \\
\hline & 3 & $0.13 \times 10^{7}$ & $0.80 \times 10^{7}$ & $0.52 \times 10^{7}$ \\
\hline & 4 & $0.80 \times 10^{6}$ & $0.12 \times 10^{7}$ & $0.13 \times 10^{6}$ \\
\hline \multirow{4}{*}{ Autumn } & 1 & $0.25 \times 10^{6}$ & $0.50 \times 10^{5}$ & $0.20 \times 10^{5}$ \\
\hline & 2 & $0.80 \times 10^{5}$ & $0.10 \times 10^{6}$ & $0.20 \times 10^{5}$ \\
\hline & 3 & $0.80 \times 10^{5}$ & $0.12 \times 10^{6}$ & 0.0 \\
\hline & $\frac{3}{4}$ & $0.60 \times 10^{5}$ & $0.12 \times 10^{6}$ & $0.20 \times 10^{5}$ \\
\hline \multirow{4}{*}{ Winter } & 1 & $0.50 \times 10^{5}$ & $0.30 \times 10^{5}$ & 0.0 \\
\hline & 2 & $0.40 \times 10^{5}$ & $0.14 \times 10^{6}$ & $0.10 \times 10^{6}$ \\
\hline & 3 & 0.0 & $0.20 \times 10^{6}$ & $0.80 \times 10^{5}$ \\
\hline & 4 & 0.0 & $0.20 \times 10^{6}$ & $0.10 \times 10^{6}$ \\
\hline \multicolumn{3}{|c|}{ 1: inlet of El-Gamil old } & \multicolumn{2}{|c|}{ 2: inlet of El-Gamil new } \\
\hline
\end{tabular}


Table 4:Bacterial count (cfu/g) of fish organs isolated from different media, locations and season 2010.

\begin{tabular}{|c|c|c|c|c|c|c|c|c|c|}
\hline \multirow{3}{*}{ Organs } & \multirow[t]{3}{*}{ Location } & \multicolumn{4}{|c|}{ Spring } & \multicolumn{4}{|c|}{ Summer } \\
\hline & & & & & & & Me & & \\
\hline & & NA & MSA & McCA & BHA & NA & MSA & McCA & BHA \\
\hline \multirow{4}{*}{ Liver } & 1 & $0.50 \times 10^{5}$ & $0.30 \times 10^{5}$ & $0.80 \times 10^{5}$ & $0.80 \times 10^{5}$ & $0.20 \times 10^{5}$ & 0.0 & $0.20 \times 10^{5}$ & $0.20 \times 10^{5}$ \\
\hline & 2 & $0.15 \times 10^{6}$ & 0.0 & $0.20 \times 10^{6}$ & $0.70 \times 10^{5}$ & $0.20 \times 10^{5}$ & 0.0 & $0.20 \times 10^{5}$ & $0.20 \times 10^{5}$ \\
\hline & 3 & $0.50 \times 10^{6}$ & $0.20 \times 10^{5}$ & $0.12 \times 10^{6}$ & $0.10 \times 10^{6}$ & $0.13 \times 10^{7}$ & 0.0 & $0.30 \times 10^{5}$ & $0.20 \times 10^{5}$ \\
\hline & 4 & $0.50 \times 10^{5}$ & 0.0 & $0.20 \times 10^{5}$ & $0.20 \times 10^{5}$ & $0.80 \times 10^{6}$ & 0.0 & 0.0 & $0.20 \times 10^{5}$ \\
\hline \multirow{4}{*}{ Gills } & 1 & $0.15 \times 10^{6}$ & $0.20 \times 10^{5}$ & $0.12 \times 10^{6}$ & 0.0 & $0.10 \times 10^{7}$ & $0.30 \times 10^{5}$ & $0.16 \times 10^{7}$ & $0.30 \times 10^{6}$ \\
\hline & 2 & $0.30 \times 10^{6}$ & $0.20 \times 10^{5}$ & $0.18 \times 10^{6}$ & $0.50 \times 10^{5}$ & $0.10 \times 10^{7}$ & $0.30 \times 10^{5}$ & $0.30 \times 10^{5}$ & $0.20 \times 10^{5}$ \\
\hline & 3 & $0.10 \times 10^{6}$ & 0.0 & $0.20 \times 10^{6}$ & $0.18 \times 10^{6}$ & $0.80 \times 10^{7}$ & $0.40 \times 10^{5}$ & $0.20 \times 10^{7}$ & $0.30 \times 10^{7}$ \\
\hline & 4 & $0.10 \times 10^{6}$ & 0.0 & $0.10 \times 10^{6}$ & $0.15 \times 10^{6}$ & $0.12 \times 10^{7}$ & $0.40 \times 10^{5}$ & $0.50 \times 10^{5}$ & $0.30 \times 10^{6}$ \\
\hline \multirow{6}{*}{ Intestine } & 1 & $0.80 \times 10^{5}$ & $0.20 \times 10^{5}$ & $0.25 \times 10^{6}$ & $0.50 \times 10^{5}$ & $0.80 \times 10^{6}$ & $0.20 \times 10^{5}$ & $0.45 \times 10^{6}$ & $0.20 \times 10^{5}$ \\
\hline & 2 & $0.20 \times 10^{6}$ & 0.0 & $0.15 \times 10^{6}$ & $0.50 \times 10^{5}$ & $0.20 \times 10^{6}$ & $0.30 \times 10^{5}$ & $0.30 \times 10^{5}$ & $0.30 \times 10^{5}$ \\
\hline & 3 & $0.80 \times 10^{5}$ & $0.20 \times 10^{5}$ & $0.15 \times 10^{6}$ & $0.80 \times 10^{5}$ & $0.52 \times 10^{7}$ & $0.20 \times 10^{5}$ & $0.30 \times 10^{5}$ & $0.30 \times 10^{5}$ \\
\hline & 4 & $0.80 \times 10^{5}$ & $0.20 \times 10^{5}$ & $0.50 \times 10^{5}$ & $0.80 \times 10^{5}$ & $0.13 \times 10^{6}$ & $0.20 \times 10^{5}$ & $0.12 \times 10^{6}$ & $0.15 \times 10^{6}$ \\
\hline & & \multicolumn{4}{|c|}{ Autumn } & \multicolumn{4}{|c|}{ Winter } \\
\hline & & NA & MSA & McCA & BHA & NA & MSA & McCA & BHA \\
\hline \multirow{4}{*}{ Liver } & 1 & $0.25 \times 10^{6}$ & $0.20 \times 10^{7}$ & $0.25 \times 10^{6}$ & $0.20 \times 10^{6}$ & $0.50 \times 10^{5}$ & $0.50 \times 10^{5}$ & 0.0 & $0.50 \times 10^{5}$ \\
\hline & 2 & $0.80 \times 10^{5}$ & $0.80 \times 10^{6}$ & $0.20 \times 10^{6}$ & $0.20 \times 10^{5}$ & $0.40 \times 10^{5}$ & 0.0 & $0.10 \times 10^{6}$ & $0.70 \times 10^{5}$ \\
\hline & 3 & $0.80 \times 10^{5}$ & 0.0 & $0.10 \times 10^{7}$ & $0.12 \times 10^{6}$ & 0.0 & 0.0 & 0.0 & 0.0 \\
\hline & 4 & $0.60 \times 10^{5}$ & 0.0 & 0.0 & $0.40 \times 10^{5}$ & 0.0 & $0.20 \times 10^{5}$ & $0.50 \times 10^{5}$ & $0.20 \times 10^{5}$ \\
\hline \multirow{4}{*}{ Gills } & 1 & $0.20 \times 10^{7}$ & $0.25 \times 10^{7}$ & $0.25 \times 10^{6}$ & $0.20 \times 10^{7}$ & $0.30 \times 10^{5}$ & 0.0 & $0.50 \times 10^{5}$ & $0.10 \times 10^{6}$ \\
\hline & 2 & $0.80 \times 10^{6}$ & $0.10 \times 10^{7}$ & $0.25 \times 10^{6}$ & $0.80 \times 10^{6}$ & $0.14 \times 10^{6}$ & 0.0 & $0.50 \times 10^{5}$ & $0.12 \times 10^{6}$ \\
\hline & 3 & $0.80 \times 10^{6}$ & 0.0 & $0.70 \times 10^{6}$ & $0.80 \times 10^{6}$ & $0.20 \times 10^{6}$ & 0.0 & $0.50 \times 10^{5}$ & $0.10 \times 10^{6}$ \\
\hline & 4 & $0.30 \times 10^{6}$ & $0.15 \times 10^{6}$ & $0.60 \times 10^{6}$ & $0.30 \times 10^{6}$ & $0.20 \times 10^{6}$ & 0.0 & $0.50 \times 10^{5}$ & $0.18 \times 10^{6}$ \\
\hline \multirow{4}{*}{ Intestine } & 1 & $0.20 \times 10^{5}$ & $0.10 \times 10^{5}$ & 0.0 & 0.0 & 0.0 & 0.0 & 0.0 & $0.80 \times 10^{5}$ \\
\hline & 2 & $0.20 \times 10^{5}$ & $0.10 \times 10^{5}$ & $0.20 \times 10^{6}$ & $0.30 \times 10^{5}$ & $0.10 \times 10^{6}$ & 0.0 & 0.0 & $0.10 \times 10^{6}$ \\
\hline & 3 & 0.0 & 0.0 & 0.0 & 0.0 & $0.80 \times 10^{5}$ & $0.50 \times 10^{5}$ & $0.30 \times 10^{5}$ & $0.80 \times 10^{5}$ \\
\hline & 4 & $0.20 \times 10^{5}$ & 0.0 & 0.0 & $0.30 \times 10^{5}$ & $0.10 \times 10^{6}$ & 0.0 & $0.50 \times 10^{5}$ & $0.18 \times 10^{6}$ \\
\hline \multicolumn{3}{|c|}{$\begin{array}{l}\text { NA: Nutrient agar, } \\
\text { BHA: Brain heart agar } \\
\text { 1: inlet of El-Gamil old } \\
\text { 3: bahr Kassab }\end{array}$} & $\begin{array}{l}\text { MacC } \\
\text { MSA: } \\
\text { 2: inle } \\
\text { 4: bah }\end{array}$ & $\begin{array}{l}\text { of El-Ga } \\
\text { Bashtier }\end{array}$ & $\begin{array}{l}\text { y agar, } \\
\text { lt agar, }\end{array}$ & & & & \\
\hline
\end{tabular}

The results reported that the high bacterial load was observed in both of gills and intestine in NA medium comparing with the liver that agree with Austin (1982) who reported that most of the microorganisms in fish tissue are thought to result from surface, gills, or intestinal contamination, where microorganisms are adsorbed on the surfaces of the fish and found in their intestinal contents. So, the initial microbial flora on the caught fish is dependent upon the contamination of the water, bottom sediment from the area of catch and the food entering the digestive tract which may contain microorganisms. Similar results were given by Chowdhury et al. (1989) and Al-Harbi (2003), they observed that the bacterial load in fish intestine was correlated with the bacterial levels in the aquatic environment.

In the present study, TBC of summer fish is related to the high TBC in summer water, the total count of bacteria obtained on NA medium was higher in summer season in all tested organs than the other seasons (spring, winter and autumn) (Table 3). Data in Table 4 exhibited higher bacterial loads of gills during all seasons than other organs (intestine and liver) in all different locations. The bacterial loads in mullet fish samples (collected from locations No. 1 and 2) were higher than Nile tilapia fish samples (from locations No. 3 and 4) in both spring and autumn seasons, while the bacterial loads of tilapia organs were high in both summer and winter seasons in locations No. 3 and 4 which are considered fresh water. TBC was $0.80 \times 10^{7}$ $\mathrm{cfu} / \mathrm{g}, 0.52 \times 10^{7} \mathrm{cfu} / \mathrm{g}$ and $0.13 \times 10^{7} \mathrm{cfu} / \mathrm{g}$ of tested organs (gills, intestine and liver, respectively) in location No. 3 (bahr kassab) during the summer. 
The highest TBC obtained on McCA, MSA, and BHA media were $0.16 \times 10^{7}$, $0.25 \times 10^{7}$, and $0.30 \times 10^{7} \mathrm{cfu} / \mathrm{g}$ of gills in locations No. 1, 1 and 3 during summer, autumn and summer, respectively. In addition, the total count of bacteria obtained on MSA medium was lower in all tested organs than the other media (NA, BHA and $\mathrm{McCA}$ ) it is probably due to that MSA is specific media for Staphylococcus spp. only.

Zaky et al. (2011) reported that there was an obvious variation in faecal coliforms counts of different fish parts of El-Bashtier and El-Mataryia areas with mean value $2.7 \times 10^{2} \mathrm{cfu} \mathrm{g}^{-1}$ for intestine in fishes of El-Bashtier area and $7.4 \times 10^{2} \mathrm{cfu}$ $\mathrm{g}^{-1}$ for intestine of fishes of El-Mataryia area. In fish taken from El-Bashtier Canal, the counts of Aeromonas spp. were higher in gill lamellae than in the intestine. However, El-Gawady (2002) counted up to $1.9 \times 10^{6}-2.4 \times 10^{6} \mathrm{cfu} / \mathrm{ml}$ total aerobic bacterial in water of fish farm in winter and summer, respectively. However, the gut and skin of $O$. niloticus microbial count reached $4.3 \times 10^{8} \mathrm{cfu} / \mathrm{g}$. Moreover, Abdelhamid et al. (2006 and 2007) registered the presence of bacteria $\left(1.3-2.0 \times 10^{5}\right)$ in samples of water, feed, sediments and fish, mainly in summer season. There was no difference between fish of natural resources and those of aquaculture concerning bacterial contamination. Also, Abdelhamid et al. (2008) found pathogenic bacteria (x $10^{6} \mathrm{cfu}$ ) in samples of intestine and liver of Nile tilapia up to 23.33, and 25.00, respectively. However, Abd El-Shahid et al. (2009) found that all fish (including Nile tilapia) samples (100) collected from Alexandria fish markets were contaminated with Enterobacteriaceae $\left(5.14 \times 10^{3}\right)$ and coliform $\left(1.02 \times 10^{3}\right)$.

\section{Bacterial isolates}

Some biochemical tests were carried for classification and identification of these isolated colonies of bacteria (Figs. 1 and 2). Eleven of Gram-negative and positive bacteria namely V. cholera, V. parahaemolyticus, Aeromonas spp., E. coli, Yersinia spp., Proteus and Pseudomonas spp. (Gram-negative rods) and S. aureus, Micrococcus spp. and S. epidermidis (Gram- positive cocci) and Bacillus spp. (Grampositive rods) were isolated from fish and identified by specific media and biochemical testes .
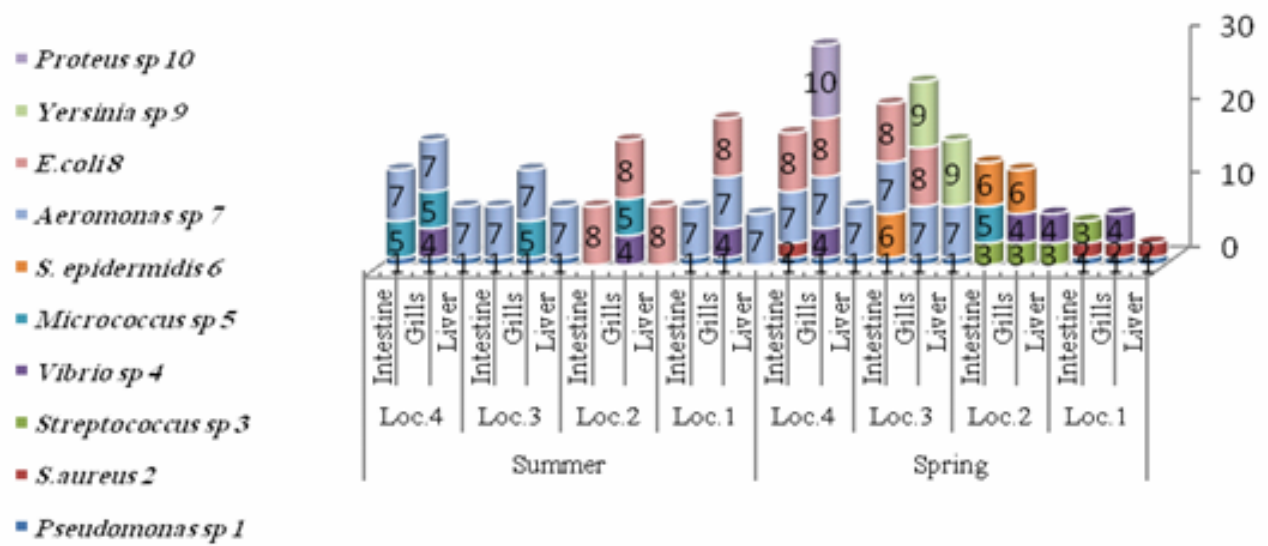

Fig. 1: Distributions of identified bacteria on different fish organs and locations during the spring and summer season 2010

In general, Pseudomonas spp., Aeromonas spp., E. coli and Vibrio spp., respectively were the most widespread in all tested organs in different locations at high temperature, Pseudomonas spp. reflected very high distribution in all organs 
(liver, gills and intestine) during summer, spring and autumn, respectively. Pseudomonas spp. almost was less prevalent in some locations as in locations No. 1 and 2 during all these seasons where the water salinity is not suitable for cultivated Pseudomonas spp.. Aeromonas spp. was the most prevalent in all organs in all locations in both summer and winter, also it was presented in locations No. 3 and 4 (fresh water) in both spring and autumn and absent in locations No. 1 and 2 where the Gram - positive bacteria were the most widespread (Streptococcus spp., Micrococcus spp. and S. aureus) in the same two seasons. Vibrio spp. was isolated from either tilapia or mullet in any season and location.

While in autumn season (Fig. 2) Staphylococcus spp. were the most common in all organs in locations No. 1 and 2 where high water salinity, while winter season reflected a lower bacterial diversity compared to the other seasons. In general, Aeromonas spp., Vibrio spp. and S. epidermidis were the most isolated from fish in this season. The presence of Enterobacteriaceae (E. coli and Proteus) in some fish organs in this study may be attributed to contaminated water with faecal matter.

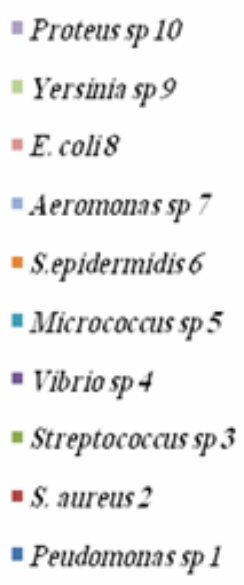

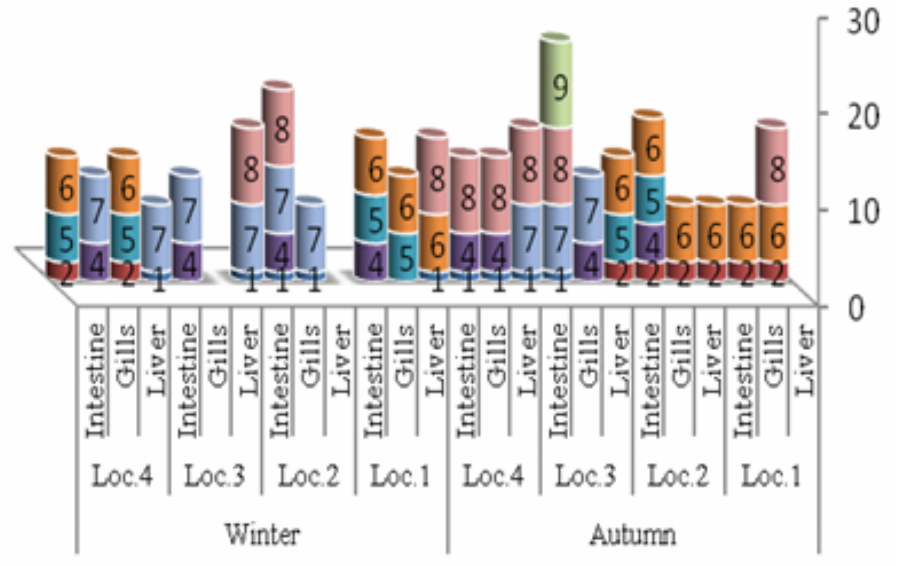

Fig. 2: Distributions of identified bacteria on different fish organs and locations during the autumn and winter season 2010/2011

These results emphasize on large amounts of domestic and agricultural waste water disposal directly or indirectly in the lake without any treatment. Leung et al. (1992); Fernandes et al. (1997) and Pullela et al. (1998) observed similar results of the feacal coliforms in tilapia (Oreochromis niloticus) intestine, and they recorded that faecal coliforms bacteria represent a potential problem in pond effluent management. Austin and Austin (1987) reported that fish harvested from water polluted with human and animal wastes can contain Salmonella, Shigella, Proteus and Escherichia coli which are usually found among the most prevalent bacteria on the most rearing water of fish. E. coli is still the most widely used indicator for faecal pollution (Snieszko and Axelrod, 1976). Also, Streptococcus spp. are opportunistic pathogens in aquaculture and their pathogenicity depends on environmental stresses as low dissolved oxygen levels, high nitrite concentration (Bunch and Bejeramo, 1997), water hardness, and crowding with water temperatures exceed $20^{\circ} \mathrm{C}$ (Ohnishi and Jo., 1983). All vital organs of fish stock infected with streptococci become heavily infected and mortality becomes massive (50-60\%). Streptococcus has been 
associated with serious economic losses among cultured freshwater and saltwater fish in many parts of the world, especially among tilapia fish (Hubbert, 1989).

Ampofo and Clerk (2003a) identified 25 species of bacteria as associated with the fish culture systems. Ampofo and Clerk (2003b) also added that manuring causes organic enrichment; it may also hasten the deterioration of the water quality making the aquatic environment favorable for the growth and multiplication of human pathogenic bacteria. Although the general microbial quality differed significantly among the production systems (source of rearing water); yet, human bacterial pathogens like E. coli and Schigella spp. were isolated from Egyptian naturally infected fishes of freshwater, mainly Oreochromis spp., Clarias lazera and common carp (Enany et al., 2004).

\section{Pathogenicity for tilapia:}

Table 5 presents the pathogenicty (\%) of bacteria isolates. Only 3 isolates ( $V$. cholera, Aeromonas spp. and Pseudomonas spp.) proved to be virulent against tilapia causing greater than $50 \%$ mortality within $96 \mathrm{hr}$. There was no death or signs of disease in control fish.

Table 5: Pathogenicity (\%) of isolates.

\begin{tabular}{|c|c|c|}
\hline Pathogenicity (\%) & Fish mortality /isolate & Bacteria \\
\hline 60 & 6 & V. cholera \\
\hline 30 & 3 & V. parahaemolyticus \\
\hline 60 & 6 & Aeromonas spp. \\
\hline 70 & 7 & Pseudomonas spp. \\
\hline 20 & 2 & Yersinia spp. \\
\hline 30 & 3 & Micrococcus spp. \\
\hline 20 & 2 & S. aureus \\
\hline
\end{tabular}

These pathogens have dangerous extracellular products and virulence linked factors. It should be called that many of these pathogens which are related to different taxonomic groups especially families of Enterobacteriaceae and Vibrionaceae, such as E. coli, Salmonella spp., Shigella spp., Vibrio spp. and Aeromonas spp. have been reported to exist in Lake Manzala (Zaky, 1995). Egyptian General Authority of Standardization and Quality Control (2000) recommended $10^{6}$ total bacterial counts per gram as a maximum permitted limit for fish, and added that fish must be free from Salmonella and Shigella. Also, Goosney et al. (2001) reported that bacterial pathogens can survive and persist to exploit their hosts cellular processes to mediate their effects extracellularly or intracellularly.

Finally, this study concludes that the bacterial load in water samples increased by increasing water temperature. The range of total count of bacteria was $0.60 \times 10^{6}$ to $0.20 \times 10^{8} \mathrm{cfu} / 100 \mathrm{ml}$ of water sample in winter and summer, respectively. Mostly, pathogenic bacteria Aeromonas spp. and Pseudomonas spp. were the most prevalent in all organs in all locations in both summer and winter, also it was present in location 3 and 4 (fresh water) in both spring and autumn and absent in locations No. 1 and 2 where the Gram - positive bacteria were the most frequently present (Streptococcus spp., Micrococcus spp. and S. aureus) where the high water salinity. The total bacterial counts were higher in gills, intestine and liver in summer than other seasons, and in general, bahr kassab and bahr Bashtier were the highest polluted by bacteria compared with the old and new El-Gamil inlets. 


\section{REFERENCES}

Abdel-Baky, T. E., Hasan, S. H. and Shallof, K. A. H. (1991). Growth of Cichild species in Lake Manzala, Egypt. Bull. Fac. Sci., Mansoura Univ., 18: 442-453.

Abdel Gawad, S. S. I.; Abdelhamid, A. M.. El-Barbary, M. I and Mabrouk, A. M. A. (2012). Benthic invertebrate fauna in Ashtoum El Gamil protected area (Lake Manzalah). Egypt. J. Aquat. Biol. \& Fish., 16 (4): 91-101.

Abdelhamid, A. M., Gawish, M. M. M and Soryal, K. A. (2006). Comparative study between desert cultivated and natural fisheries of mullet fish in Egypt, II- microbiological concern. J. Agric. Sci. Mansoura Univ., 31: 56815687.

Abdelhamid, A. M., Fayed, A. M. Ghanem A. Z. and Helal H. G. (2007). Studies on biological treatment of salt plants. II- Fattening trial. J. Agric. Sci. Mansoura Univ., 32 : $151-165$.

Abdelhamid, A. M., El-Fadaly, H. A and Ibrahim, S. M. (2008). Studies on integrated fish/duck production system: III- Microbiological concern. Egyptian J. Nutrition and Feeds, 11 (1) : 215 - 227.

Abd El-Shahid, Y. S. Y., Khalil H. A and Samaha I. A. (2009). Some enteropathogenic bacteria isolated from freshwater fish at Alexandria province. Global Fisheries \& Aquaculture Research Conference, 24-26 Oct., Cairo International Conventions Center, www.fishtechexpo.org, Book of Abstracts, p:27.

Al-Harbi, A. H. (2003). Faecal coliforms in pond water, sediments and hybrid tilapia Orecochromis niloticus $\times$ Oreochromis aureus in Saudi Arabia. Aquacul. Res., 34: 517-524.

Ampofo, J. A. and Clerk, G. C. (2003 a). Diversity of bacteria in sewage treatment plant used as fish culture pond in southern Ghana. Aquacul. Res., 34 (8): 667.

Ampofo, J. A. and Clerk, G. C. (2003 b). Short communication: Bacterial flora of fish feeds and organic fertilizers for culture ponds in Ghana. Aquacul. Res., 34 (8): 677.

Atlas R.M. and Bartha R. (1993) Microbial Ecology - fundamentals and applications. Redwood City: Benjamin-Cummings Plublishing Co.

Austin, B. (1982). Taxonomy of bacteria isolated from a coastal-marine fish - rearing unit. J. Appl. Bacteriol., 53: 253 - 268.

Austin, B. and Austin, D.A. (1987). Bacterial Fish Pathogens: disease in farmed and wild fish. Ellis Horwood, Chichester.

Bunch, E. C. and Bejerano I. (1997). The effect of environmental factors on the susceptibility of hybrid tilapia $O$. niloticus and $O$. aureus to streptococcosis, Isr. J. Aquacul., 49:67-76.

Chowdhury, M. B. R., Muniruzzaman, M and Uddin, M. N (1989). Study on the intestinal bacterial flora of tilapia Oreochromis niloticus. Bangladesh J. of Aquacul., 11: 65-70.

Clark, I. A. and Pagel, J. E. (1977). Pollution indicator bacteria associated with municipal raw and drinking water supplies. Canad. J., 28: 465-470. 
EEAA. (1999).Annual report of the Environmental Data from Coastal Areas of the Mediterranean Sea in1999. EEAA, Cairo, Egypt.

Egyptian General Authority of Standardization and Quality Controll (EGASQC) (2000). Cairo, Egypt (ES 344 - 2000).

El-Gawady, M. M. M. (2002). Study on microbial pollution types in Manzal lake. M.Sc. Thesis, Fac. of Agric., Mansoura Univ.

El-Naggar, M.M.A., El-Masry, M.H. and El-Shenawy, M.A. (2003). Distribution of some dominant bacteria in Alexandira eastern harbour that can be used as marine contaminate indicator. Bull. Nat. Inst. of Oceanogr. Fish., 29: $323-336$

El-Shenawy, M.A. and Farag, A.M. (2005). Spatial and temporal variability of saprophytic and water quality bacteria along the coast of Aqaba,Suez gulfs and Red Sea- Egypt. Egyptian J. Aquat. Res., 31: 157-69

Enany, M.E., El-Sayed, M.E., Diab, A.S., Hassan, S.M. and El-Gamal, R.M. (2004). Bacterial causes of fin rot in some fresh water fishes. Proc. $6^{\text {th }}$ Int. Symp. on tilapia in Aquaculture. Manila, Philippines, Sept. $12-15$, p: 229.

Fernandes C. F., G. J. Flick, J. L. Silva and T. A. McCasky (1997). Influence of processing schemes on indicative bacteria and quality of fresh aquacultured catfish fillets. J. of Food Protec., 60: 54-58.

Goosney, D.L., Knoechel, D.G. and Finlay, B.B. (2001). Enteropathogenic E. coli, Salmonella, and Shigella: Masters of host cell cytoskeletal exploitation. File: //D:IDR_MAHAlgoosney.htm.

Hamed Y. A., Abdelmoneim T. S., ElKiki M. H., Hassan M. A and Berndtsson R. (2013). Assessment of heavy metals pollution and microbial contamination in water, sediments and fish of Lake Manzala, Egypt . Life Sci. J., 10 (1): 86-99.

Holt, J. G., Krieg, N. R. Sneath, P. H. A.and Williams, S.T. (1994). Bergey's Manual of Determinative Bacteriology, 9th ed. Williams and Wilkins, Baltimore.

Hubbert, R.M. (1989). Bacterial diseases in warm water aquaculture. Shilo, M. and Sarig, S. (Eds.) Fish Culture in Warm Water System: Problems and Trends, CRC Press. Boca Rotan, Florida. 179-194.

Ibrahim, M. (1993). Protected Area in Egypt. NCS, EEAA. (In Arabic).

Kosygin, L., Dhamendra, H. and Gyaneshwari, R. (2007). Pollution status and conservation strategies of Moirang river, Manipur with a note on its aquatic bio-resources. J. Environ. Biol., 28, 669-673.

Lara, J.G., Moenon, P., Servais, P. and Billen, G., (1991). Mortality of fecal bacteria in seawater. Appl. Environ. Microbiol., 57: 885-8.

Leung C., Huang, Y. and Pancorbo, O. (1992). Bacterial pathogens and indicators in catfish and pond environments. J. of Food Protec., 55: 424-427.

Mancini, J.L., (1978). Numerical estimates of coliform mortality rates under various conditions. J. Water Pollut. Cont. Fed., 50: 2477-84. 
Marcel, K.A., Antoinette, A.A and Mireille, D. (2002). Isolation and characterization of Aeromonas species from an eutrophic tropical estuary. Mar Pollut Bull. Dec., 44 (12): 1341-4.

Meininger, P. L. and Atta, G. (1994) Ornit+hological studies in Egyptian wetlands 1989/90. Netherlands: FORE (Report No. 94 01).

Ohnishi, K. and Jo, Y. (1983). Studies on streptococcal infection in pond- cultured fishes: 1, isolated from cultured ayu and among in 1977-1978. Fish Pathol., 16:63-67.

Platt, T., Sathyendranath, S. and Stuart, V. (2006). Why study biological oceanography? Aquabiol., 28: 542-557.

Pullela S., Fernandes, C. F. Flick, G. J. Libey, G. S. Smith and S. A. Coale, C. W. (1998). Indicative and pathogenic microbiological quality of aquacultured finfish grown in different production systems. J. of Food Protec., 61: 205-210.

Rose, J. S., Chassin, L., Presson, C. C. and Sherman, J. S. (1996) Prospective predictors of quit attempts and smoking cessation in young adults. Health Psychol., 15: 261-268.

Sathware, N.G., Paterl, K.G. Vyas, J.B., Patel, S., Trivedi, M.R., Dave, L.M., Madia, M.M., Kulkarni. P.K., Parikh, D.J. and Saiyed, H.N.(2007). Chromium exposure study inchemical based industry. J. Environ. Biol., 28: 405408.

Sciavano, G.F, Bruscolini,F, Albano, A and Brandi, G.(1998). Virulence factors in Aeromonas sppand their association with gastrointestinal disease. NewMicrobiol. Jan; 21(1).,23-30.

Shaltout, K.H., Galal T.M and El-Komi, T.M. (2009). Evaluation of the nutrient status of some hydrophytes in the water courses of Nile Delta, Egypt. J. Bot., $10.1155 / 2009 / 862565$.

Snieszko, A. and Axelrod, S. (1976). Chemical factors in diseases. In: Diseases of Fishes, ed., T.F.H. Publication, Inc. Itd. Washington.

Subramanyam, N.S. and Sambamurty, A.V.S.S.(2006). Ecology, $2^{\text {nd }}$ Edn., Narosa Publishing House, New Delhi.

Uddin M. N., Islamand, M. N.and Rahman, M. A. (1990). Comparative studies on the seasonal variation in viable bacterial counts of two artificial lakes. Progress. Agricul.; 1: 59-63.

Zaky, M.M. (1995). Microbiological and Toxicological study of the environmental pollution of Lake Manzala. M.Sc. Thesis, Faculty of Science, Suez Canal University, Egypt.

Zaky, M.M. (2004). Study on the microbial pollution and molecular biology of some pathogenic species in Lake Manzala. Ph.D. Thesis. Mansoura University. Egypt

Zaky, M.M., Salem, M., Persson,K.M. and Eslamian S. (2011). Incidence of Aeromonas species isolated from water andfish sources from Lake Manzala (Egypt). Int. J. of hydrology Sci. \& Tech. 


\title{
ARABIC SUMMERY
}

\author{
الحالة البكتريولوجية لمحمية أشتوم الجميل

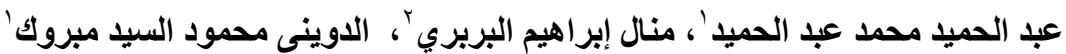

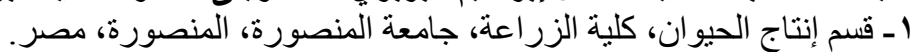

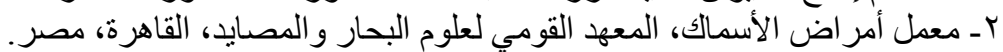

تم إجر اء در اسة مسحية خلال فصول السنة الأربعة من أربعة مو اقع تمثل مساحة محمية أثنتوم الجميل -

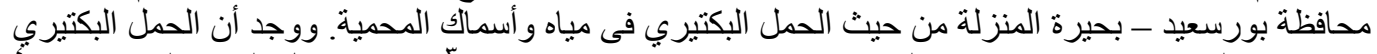

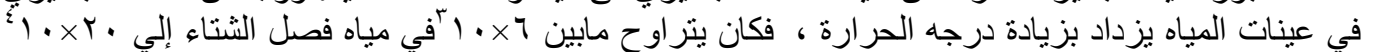

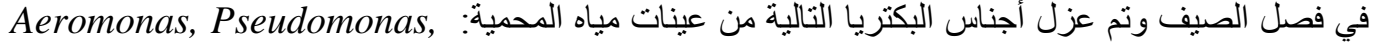
Bacillus, Proteus, Streptococcus, S. epidermidis, S. aureus, Micrococcus, Vibrio and

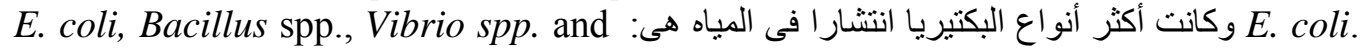
Pseudomonas spp. and BHA

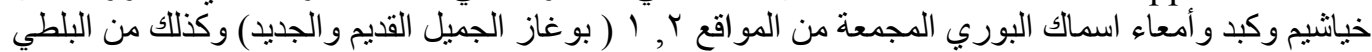

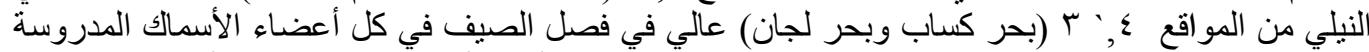

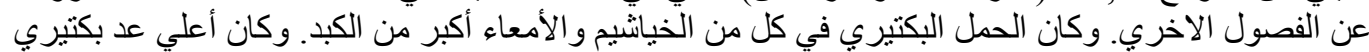

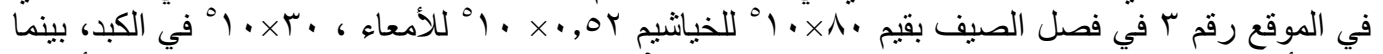

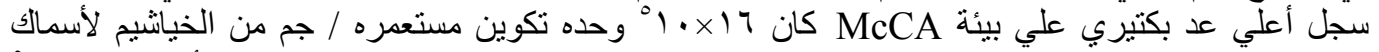

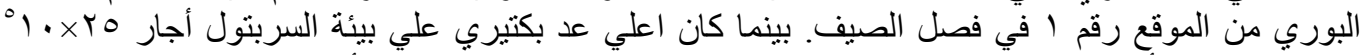

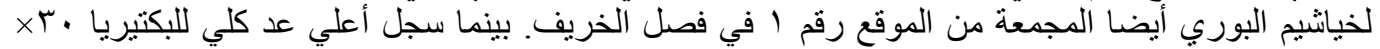

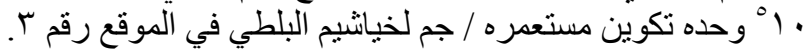

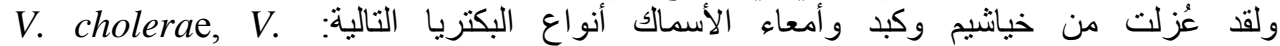
parahaemolyticus, Aeromonas spp., E. coli, Yersinia spp., Proteus, Pseudomonas spp., Micrococcus spp., S. epidermidis, S. aureus and Streptococcus spp.

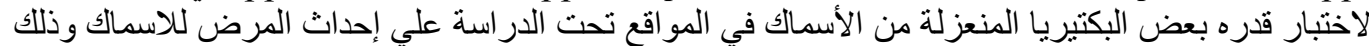

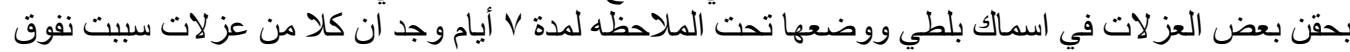
بع. cholera and Aeromonas spp. Pseudomonas spp., 